Slates in the walls of the magma reservoirs and vents and would be incorporated into the magma only in conditions of excess gas pressures such as might occur during periods of welded tuff formation.

Department of Geology,

R. J. Firman. 19 th June, 1956.

UNIVERSITY OF NOTTINGHAM.

\title{
NEW NAME FOR LIAS AMMONITE
}

SIR,-Prof. R. Trümpy, of Zürich, has kindly called my attention to the fact that my Blue Lias ammonite, species, Psiloceras (Caloceras) multicostatum Donovan, 1952, p. 638, is homonymous with Psiloceras (Caloceras) multicostatum Brandes, 1912, p. 431, proposed for Quenstedt, 1883, pl. 1, fig. 12. I therefore propose Psiloceras (Caloceras) bloomfieldense nom. nov. for $P$. (C.) multicostatum Donovan, 1952, non Brandes, 1912, holotype to be the same specimen as for my earlier species, namely Geological Survey Museum no. 85017. The specific name is derived from Bloomfield Quarry, Farmborough, Somerset, the type locality.

\section{REFERENCES}

Brandes, T. 1912. Die faziellen Verhältnisse des Lias zwischen Harz und Egge-Gebirge mit einer Revision seiner Gliederung, Neues Jahrb. Min., Beil.-Bd. xxxiii, 325-508.

Donovan, D. T. 1952. The Ammonites of the Blue Lias of the Bristol District, Part I, Psiloceratidae and Schlotheimidae, Ann. Mag. Nat. Hist., ser. 12, v, 629-655.

QUENSTEDT, F. A. 1883. Die Ammoniten des Schwäbischen Jura. Bd. I, part 1, Stuttgart.

Geology Department, D. T. Donovan.

THE UNIVERSITY,

BRISTOL, 8.

1 st August, 1956.

\section{THE BOUNDARY BETWEEN MIDDLE AND UPPER JURASSIC}

SIR,-Dr. Arkell's new book, Jurassic Geology of the World (1956), is a masterpiece in conception and execution, and all students of the Jurassic system will be indebted to his immense labours and to his clarity of exposition and synthesis, as well as to the publishers for a style of production worthy of this majestic undertaking. In a book where almost every detail and generalization is based on fact or common sense, it is all the more disturbing to find a statement that alters all established usage in Jurassic stratigraphy, and this without a word of satisfactory explanation or supporting stratigraphical evidence.

This statement is the inclusion of the Callovian stage in the Middle Jurassic (p. 8), a step taken, apparently, only so that the table of stages and zones on p. 7 may look neater, and in order to conform with the " priority" of von Buch's arrangement of 1839 . It is quite inconsistent with the author's stated preference for " a compromise between priority, suitability and usage" (p. 8) and with his rejection (p. 7) of " ancient terms and meanings of before 1850 "; in fact, from its very date, it cannot have been a grouping of stages or zones within the author's self-imposed terms of reference. As for priority, von Buch's scheme is inconsistent with that proposed in England by Conybeare and Phillips in 1822 . It was, moreover, Oppel's considered opinion (1858, p. 821) that it should be replaced in England, France, and South-West Germany by a modified version of Conybeare and Phillips's scheme, which had been widely used up to that time and has been universally used ever since. 